SECTION 31. Economic research, finance, innovation.

Khapayev Ilyas Borisovich candidate of philosophical Sciences, associate Professor, head of the Department of Economics, management and Finance law Karachaevo-Cherkessia branch, Russian state social University, Cherkessk, Russia ilyas.xapaev@yandex.ru

\title{
THE LIVESTOCK INDUSTRY AND ITS ROLE IN THE DEVELOPMENT OF THE AGRICULTURAL SECTOR KAIAKENT MUNICIPAL DISTRICT OF DAGESTAN
}

Abstract: This article assesses the current state of the livestock industry of the municipality of the Republic of Dagestan, is determined by its role in the agricultural sector of the economy, identifies the problematic issues in the dynamics of the development of animal husbandry and measures to address them

Key words: animal, peasant (farmer's) economy, sheep, Kayakentsky municipal area, private farms, agricultural products, agriculture, agricultural organizations, ranching.

УДК 338.43

ББК 45/46

\section{ЖИВОТНОВОДЧЕСКАЯ ОТРАСЛЬ И ЕЕ РОЛЬ В РАЗВИТИИ АГРАРНОГО СЕКТОРА ЭКОНОМИКИ КАЯКЕНТСКОГО МУНИЦИПАЛЬНОГО РАЙОНА РЕСПУБЛИКИ ДАГЕСТАН}

\begin{abstract}
Аннотация: В статье проводится оценка современного состояния животноводческой отрасли муниципалитета Республики Дагестан, определяется ее роль в сельскохозяйственном секторе экономики, выявляются проблемные вопросы в динамике развития животноводства и меры по их устранению
\end{abstract}

Ключевые слова: животноводство, крестьянские (фермерские) хозяйства, овцеводство, Каякентский муниципальный район, личные хозяйства населения, продукция сельского хозяйства, сельское хозяйство, сельскохозяйственные организации, скотоводство.

Каякентский район - один из самых крупных по занимаемой территории районов Республики Дагестан. Район расположен в юго-восточной части Дагестана и граничит с Дербентским, Кайтагским, Сергокалинским и Карабудахкентским районами республики. Находится на побережье Каспийского моря, площадь территории - 691 кв. км [1]. Районным центром является село Новокаякент.

На территории района расположены 19 населенных пунктов, объединенных в 14 муниципальных образований [2]:

- Сельсовет «Алхаджакентский» (сёла Алхаджакент и Гаша);

- село Башлыкент;

- село Герга;

- село Джаванкент;

- село Дружба;

- село Капкайкент;

- село Каранайаул;

- Сельсовет «Каякентский» (сёла Каякент и Кулкам);

- Сельсовет «Нововикринский» (сёла Новые Викри и Викри);

- Сельсовет «Новокаякентский» (сёла Новокаякент и Инчхе); 
- село Первомайское;

- Сельсовет «Сагаси-Дейбукский» (сёла Сагаси-Дейбук и Дейбук);

- село Усемикент;

- село Утамыш.

В муниципальных образованиях района по данным на первое января 2012 года проживают 54098 человек. Состав населения муниципальных образований характеризуется данными таблицы 1.

Таблица 1

\section{Муниципальные образования Каякентского муниципального района Республики Дагестан и состав их населения по данным на 1 января 2012 года [3]}

\begin{tabular}{|c|c|c|c|}
\hline Наименование муниципального образования & \multirow{2}{*}{$\begin{array}{c}\text { Все } \\
\text { население } \\
\text { (чел.) }\end{array}$} & $\begin{array}{c}|c| \\
\text { городское } \\
\text { население }\end{array}$ & $\begin{array}{c}\text { сельское } \\
\text { население }\end{array}$ \\
\hline Сельское поселение сельсовет Алхаджакентский & 2440 & - & 2440 \\
\hline Сельское поселение село Башлыкент & 3109 & - & 3109 \\
\hline Сельское поселение село Герга & 3883 & - & 3883 \\
\hline Сельское поселение село Дружба & 3695 & - & 3695 \\
\hline Сельское поселение село Джаванкент & 968 & - & 968 \\
\hline Сельское поселение село Капкайкент & 962 & - & 962 \\
\hline Сельское поселение село Каранайаул & 1721 & - & 1721 \\
\hline Сельское поселение сельсовет Каякентский & 11591 & - & 11591 \\
\hline Сельское поселение сельсовет Нововикринский & 3446 & - & 3446 \\
\hline Сельское поселение сельсовет Новокаякентский & 5288 & - & 5288 \\
\hline Сельское поселение село Первомайское & 9088 & - & 9088 \\
\hline Сельское поселение сельсовет Сагаси-Дейбукский & 2429 & - & 2429 \\
\hline Сельское поселение село Усемикент & 2003 & - & 2003 \\
\hline Сельское поселение село Утамыш & 3475 & - & 3475 \\
\hline
\end{tabular}

Как свидетельствуют данные таблицы 1 , все население района сосредоточено в сельских поселениях, более густонаселенными из которых являются сельское поселение «Сельсовет Каякентский» - 11591 чел., сельское поселение «село Первомайское» - 9088 чел., сельское поселение «Сельсовет Новокаякентский» - 5288 чел.

В остальных муниципальных образованиях размещение населения носит более равномерный характер: численность колеблется от 962 чел. (сельское поселение «Капкайкент») до 3883 чел. (сельское поселение «село Герга»).

На основании данных таблицы 1 приходим к тому, что основой экономики в соответствии с ее населением является аграрный сектор, основными отраслями которого являются виноградарство, овощеводство, растениеводство, рыболовство.

При этом следует добавить, что на долю АПК приходится более 80 процентов валового продукта района [4]. Общий объем производства сельхозпродукции составляет до 1 млрд. рублей в год. Непоследнюю роль в развитии аграрного сектора 
играет и животноводческая отрасль района, представленная в первую очередь овцеводческой и скотоводческой отраслями.

Хозяйствами муниципалитета в среднем ежегодно производится:

- винограда - до 40 тыс. тонн;

- зерна - 14-16 тыс. тонн;

- овощей - 6-8 тыс. тонн;

- молока - 7 тыс. тонн;

- мяса - 2,5 тыс. тонн [5].

В районе функционируют 13 сельскохозяйственных предприятий и 292 крестьянских (фермерских) хозяйства. Частное подворье также вносит весомый вклад в развитие сельского хозяйства, в частности животноводческой отрасли муниципалитета. Среди них выделяются ГУП «Кировский», ГУП «Каспий», СПК «Нововикринский», ГУП «Каякентский», ГУП «Башлыкентский», ГУП «Каякентский», ГУП «Башлыкентский», ГУП «Кировский», КФХ «Исток», КФХ «Руслан» и др.

Рассмотрим динамику развития животноводческой отрасли района в целом по данным таблицы 2.

Таблица 2

Поголовье скота в хозяйствах Каякентского муниципального района Республики Дагестан на конец года, голов [6]

\begin{tabular}{|c|c|c|c|c|c|}
\hline Годы & $\begin{array}{l}\text { Крупный } \\
\text { рогатый } \\
\text { скот }\end{array}$ & $\begin{array}{c}\text { В том числе коровы } \\
\text { (без коров на } \\
\text { откорме и нагуле) }\end{array}$ & $\begin{array}{c}\text { Овцы } \\
\text { и козы }\end{array}$ & Лошади & Овцекозоматки \\
\hline \multicolumn{6}{|c|}{ Хозяйства всех категорий } \\
\hline 2011 & 8732 & 4126 & 13076 & 55 & 7788 \\
\hline 2012 & 8767 & 4011 & 13684 & 92 & 8406 \\
\hline 2012 в \% 2011 & 100,4 & 97,2 & 104,7 & 167,3 & 107,9 \\
\hline \multicolumn{6}{|c|}{ Сельскохозяйственные организации } \\
\hline 2011 & 1299 & 455 & 4490 & 26 & 2611 \\
\hline 2012 & 1146 & 382 & 4010 & 21 & 2500 \\
\hline 2012 в \% 2011 & 88,2 & 84,0 & 89,3 & 80,8 & 95,7 \\
\hline \multicolumn{6}{|c|}{ Хозяйства населения } \\
\hline 2011 & 7162 & 3546 & 7484 & 25 & 4467 \\
\hline 2012 & 7266 & 3456 & 7384 & 59 & 4353 \\
\hline 2012 в \% 2011 & 101,5 & 97,5 & 98,7 & 236,0 & 97,4 \\
\hline \multicolumn{6}{|c|}{ Крестьянские (фермерские) хозяйства и индивидуальные предприниматели } \\
\hline 2011 & 271 & 125 & 1102 & 4 & 710 \\
\hline 2012 & 355 & 173 & 2290 & 12 & 1553 \\
\hline 2012 в \% 2011 & 131,0 & 138,4 & 207,8 & 300,0 & 218,7 \\
\hline
\end{tabular}

Как показывают данные таблицы 2, за 2012 год по сравнению с предыдущим годом поголовье крупного рогатого скота по району возросло на 0,4\%, при этом численность поголовья коров (без коров на откорме и нагуле) снизилась на 2,8\%. Увеличение поголовья крупного рогатого скота произошло за счет роста их численности в крестьянских (фермерских) хозяйствах и у индивидуальных 
предпринимателей и на частном подворье на $31,0 \%$ и 1,5\% соответственно. При этом следует заметить, что в сельскохозяйственных организациях наблюдается заметное сокращение поголовья крупного рогатого скота (на 11,8\%).

Таким образом, отрадно говорить, что в 2012 году по сравнению с аналогичным показателем предыдущего года по Каякентскому муниципальному району Республики Дагестан численность крупного рогатого скота увеличилась в целом на 35 голов.

Но при этом следует заметить, что поголовье коров (без коров на откорме и нагуле) сократилось на 115 голов, что, несомненно, отразится на показателях молочного скотоводства, продукция которого является основой продовольственной безопасности данного муниципалитета.

Как показывают данные таблицы 2, вышеизложенное обстоятельство произошло в первую очередь за счет заметного их сокращения в сельскохозяйственных организациях и на частном подворье - на $16,0 \%$ и $2,5 \%$ соответственно.

Но при этом следует отметить тот факт, что основным стабилизирующим динамику развития животноводческой отрасли, фактором стал заметный рост численности коров в крестьянских (фермерских) хозяйства и у индивидуальных предпринимателей - на 38,4\%.

Вышеизложенное говорит о некоторой стабилизации и динамичности развития скотоводческой отрасли района в целом, но при этом наблюдается тревожная тенденция сокращения численности поголовья коров (без коров на откорме и нагуле) в сельскохозяйственных организациях и, самое главное, в личных хозяйствах населения, которые выступают основным поставщиком скотоводческой продукции, гарантом продовольственной безопасности жителей района.

Что касается состояния овцеводческой отрасли, то как свидетельствуют данные таблицы 2, численность овец и коз увеличилась в 2012 году по сравнению с аналогичным показателем 2011 года на 608 голов (на 4,7\%) и достигла 13684 головы. Данное обстоятельство произошло за счет роста численности овец и коз в крестьянских (фермерских) хозяйствах и у индивидуальных предпринимателей на $107,8 \%$. В сельскохозяйственных организациях и на частном секторе поголовье овец и коз заметно сократилось (на $10,7 \%$ и $1,3 \%$ соответственно).

В численности поголовья овцекозоматок в рассматриваемом периоде по району также наблюдается заметное их увеличение - на 7,9\%. Это произошло главным образом за счет роста данного показателя в крестьянских (фермерских) хозяйствах и у индивидуальных предпринимателей (на 118,7\%).

В частном же подворье и в сельскохозяйственных организациях выявляется несколько иная ситуация: поголовье козоматок существенно сократилось - на 2,6\% и 4,3\% соответственно. На сегодняшний день в Каякентском муниципальном районе Республики Дагестан численность овцекозоматок согласно данным таблицы 2 составляет 8406 голов.

В данном муниципалитете быстрыми темпами идет восстановление и развитие коневодства, которое практически прекратило свое существование в начале 90-х годов прошлого века, в годы становления рыночной экономики. На данном этапе своего развития в коневодческой отрасли животноводства района, как показывают данные таблицы 2, насчитывается 92 головы. По сравнению с 2011 годом в 2012 году темп прироста лошадей в хозяйствах всех категорий района составил 67,3\%. При этом необходимо отметить, что заметное их увеличение произошло в крестьянских (фермерских) хозяйствах и у индивидуальных предпринимателей и на частном подворье - на 200,0\% и 136,0\% соответственно. Существенное снижение данного показателя 2012 года по сравнению с аналогичным показателем прошлого периода произошло в сельскохозяйственных организациях - на 19,2\%. 
Если же посмотреть на структуру животноводческой отрасли в целом, то основная доля во многих ее направлениях принадлежит личным хозяйствам населения. Об этом более наглядно показано на рис. 1-3.

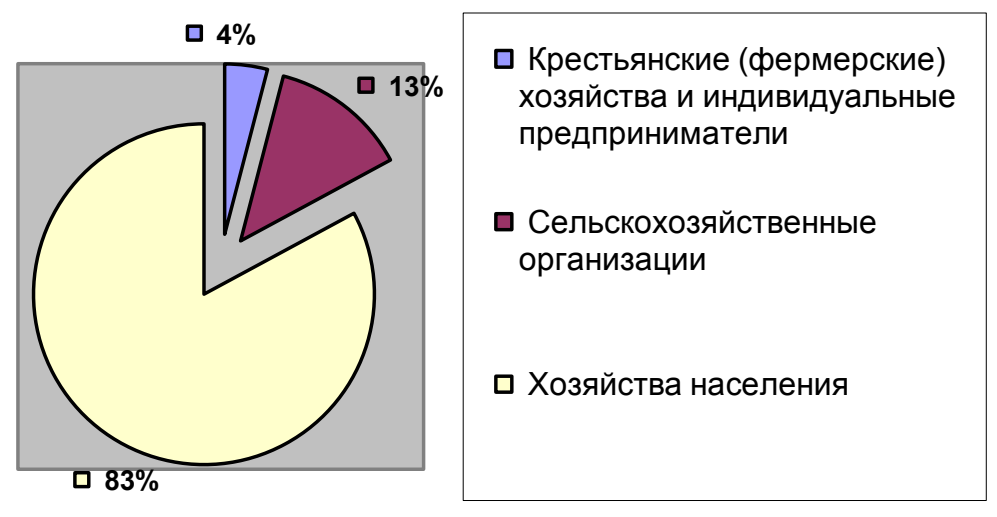

Рисунок 1 - Структура численности крупного рогатого скота (в том числе коров) в Каякентском муниципальном районе Республики Дагестан в 2012 году.

Как свидетельствуют данные рис. 1, в структуре численности крупного рогатого скота (в том числе коров) района в 2012 году доля частного подворья составляет 83\%, которая превышает аналогичный показатель идущих на втором месте сельскохозяйственных организаций на 70\% (13\%), которые в свою очередь опережают крестьянские (фермерские) хозяйства и индивидуальных предпринимателей на 9\% $(4 \%)$.

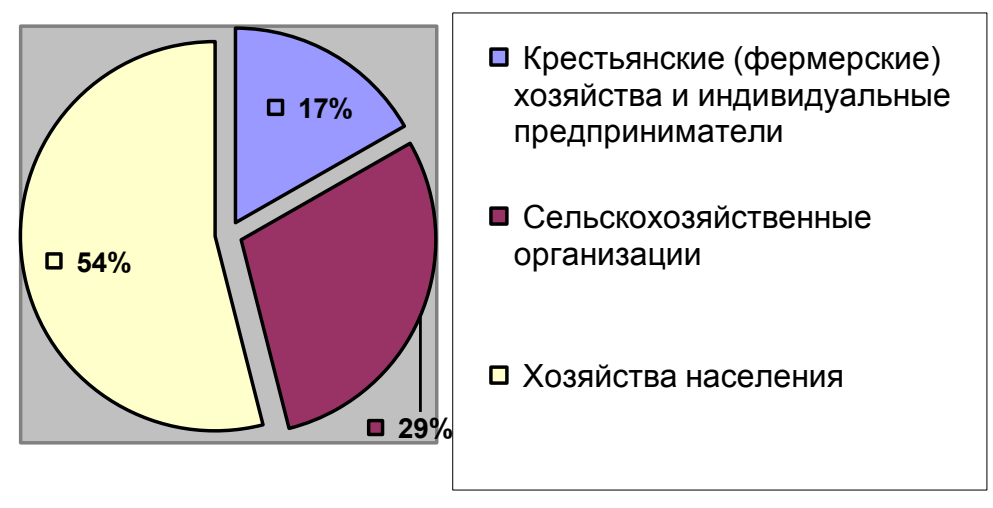

Рисунок 2 - Структура численности овец и коз (в том числе овцекозоматок) в Каякентском муниципальном районе Республики Дагестан в 2012 году

Данные рис. 2 показывают, что в структуре овцеводческой отрасли района основная доля также принадлежит частному сектору - 54\%, которая опережает идущих на втором месте сельскохозяйственных организаций на $25 \%$ (29\%), которые в свою очередь опережают крестьянские (фермерские) хозяйства и индивидуальных предпринимателей на $12 \%$ (17\%). 


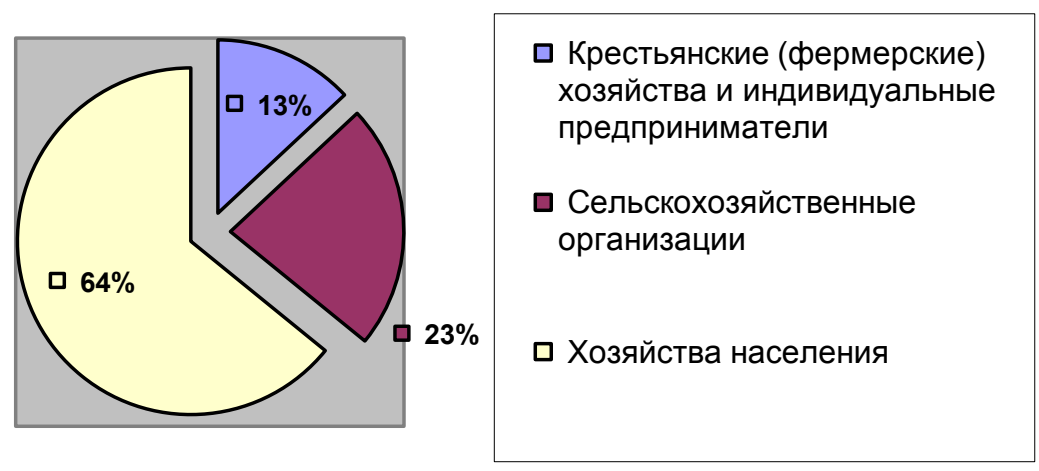

\section{Рисунок 3 - Структура численности лошадей в Каякентском муниципальном районе Республики Дагестан в 2012 году.}

Если же посмотреть на сложившуюся ситуацию в структуре коневодческой отрасли муниципалитета, то согласно данным рис. 3 основная доля приходится на частное подворье - 64\%, которая превышает долю сельскохозяйственных организаций - на $41 \%$ (23\%) и крестьянских (фермерских) хозяйств и индивидуальных предпринимателей на 51\% (13\%).

Вышеизложенное позволяет с уверенностью говорить о том, что практически вся животноводческая отрасль сельского хозяйства Каякентского муниципального района Республики Дагестан развивается главным образом за счет частного подворья. Данное обстоятельство подтверждается следующими данными: доля в структуре численности крупного рогатого скота $-83 \%$, мелкого рогатого скота $-54 \%$ и лошадей $64 \%$.

В связи с этим следует подчеркнуть, что именно частное подворье выступает главным поставщиком животноводческой отрасли и гарантом продовольственной безопасности жителей муниципальных образований района.

Проведенный анализ состояния животноводческой отрасли муниципальных образований района достаточно ясно показывает, что в хозяйствах муниципалитета имеется ряд существенных факторов, тормозящих ее развитие, среди которых выделяются:

- слабое финансовое состояние частного подворья;

- диспаритет цен и слабый сбыт животноводческой продукции;

- отсутствие перерабатывающих предприятий;

- большая сумма первоначальных взносов кредита, залоговую базу которого далеко не каждый рядовой труженик села сможет обеспечить;

- отток населения в северные районы региона;

- неудовлетворительное состояние системы мелиорации отдельных территорий района и т.д.

Для решения обозначенных проблем необходимо, на наш взгляд, принять следующие меры.

Безусловно, существуют региональные и федеральные отраслевые программы, согласно которым предусмотрено субсидирование развития частного сектора, но при этом необходимо учесть тот факт, во-первых, наличие во многих программах первоначального взноса, которого не под силу внести многим частникам, во-вторых, 
обойти даже все бюрократические барьеры для его получения, порою даже и невозможно простому труженику села.

Один из действенных механизмов решения вышеизложенных проблем предлагают Гаджиева У.А., Халимбекова Э.А., согласно мнению которых «....в целях устранения трудностей в сбыте сельскохозяйственной продукции и преодоления локального монополизма в сфере переработки целесообразно кооперировать и интегрировать сельхозтоваропроизводителей, переработчиков сырья и торговлю путем создания соответствующих интегрированных структур» [7].

В целях регулирования рынка сбыта сельскохозяйственной продукции необходимо вернуться к советскому опыту, в соответствии с которым практически в каждом районе были так называемые заготовительные пункты, которые занимались приемом именно животноводческой продукции.

На наш взгляд, необходимо строительство и введение в строй на территории района с учетом особенностей и условий сельских поселений нескольких мини-цехов по производству мясо- и молочных продуктов, что также будет способствовать появлению новых рабочих мест.

Отток населения из села происходит главным образом из-за безработицы, отсутствия должного социального пакета, слабой инфраструктуры муниципального образования [8] и, прежде всего, низкой заработной платы, средняя сумма которой по республике в отраслях сельского хозяйства составляет всего 5-6 тыс. рублей. Перечисленные факторы, безусловно, оказывают негативное влияние и на кадровое обеспечение субъектов хозяйствования животноводческой отрасли.

В связи чем, на наш взгляд, необходимо в первую очередь создавать дополнительные рабочие места в сельскохозяйственных организациях путем привлечения дополнительных инвестиций, улучшения социальной обеспеченности сельского жителя, увеличения заработной платы на селе, улучшения жилья и т.д.

Одним из существенных способов улучшения состояния системы мелиорации отдельных территорий района является внедрение так называемой системы капельного орошения, которая позволит «...не только кратно уменьшать количество потребляемой воды, но при этом многократно увеличивает урожайность, качество продукта, значительно сокращает расходы, повышаются рентабельность, доходность» [9].

Одним из методов решения выявленных проблем являются наращивание ресурсного потенциала в сельском хозяйстве, создание собственной переработки сельскохозяйственного сырья, воспроизводство крупного рогатого скота путем закупки племенных пород в ведущих странах мира в данной сфере, восстановление мелиоративной системы [10].

Решение обозначенных проблем путем внедрения предложенных мер, безусловно, позволит укрепить и создать необходимые условия для дальнейшего, и, самое главное, успешного и более динамичного развития животноводческой отрасли Каякентского муниципального района Республики Дагестан.

\section{Библиографический список:}

1. Каякентский район [Электронный ресурс]. URL: http://president.e-dag.ru (дата обращения 24.06.2013 г.).

2. Ст. 17 Закона «О статусе и границах муниципальных образований Республики Дагестан» № 6 от 13.01.2005 года.

3. Численность населения Российской Федерации по муниципальным образованиям на 1 января 2012 года. // Ст. бюллетень // Росстат. - М. , 2012. 
4. Алиева Элиза. Дагестан. Нариман Абдуразаков: «Необходимо усилить работу по минимизации влияния мирового финансового кризиса на экономику район [Электронный ресурc]. URL: http://fermer.ru (дата обращения 19.07.2013 г.).

5. Каякентский район [Электронный ресурс]. URL: http://president.e-dag.ru (дата обращения 21.07.2013 г.).

6. Итоги учета скота / Дагстат // Стат. бюллетень сельского хозяйства. Махачкала, 2013. С. 4-14.

7. Гаджиева У.А., Халимбекова Э.А. Анализ затрат в выращивании скота на мясо в сельскохозяйственных предприятиях южной равнинной подзоны Дагестана // Проблемы современной экономики. №3 (31), 2009. - Санкт-Петербург, 2009. С. 441.

8. Хапаев И.Б. Животноводческая отрасль Кизлярского муниципального района Республики Дагестан и динамика ее развития в современных условиях // Бизнес. Образование. Право. Вестник Волгоградского института бизнеса. Вып. №3(24). Волгоград, 2013. С. 117-121.

9. Газиев Заур, Абдулахидов Магомед. Нет таких вопросов, которые не касались бы главы района! [Электронный ресурс]. URL: http://mahachkala.bezformata.ru (дата обращения 22.07.2013 г.).

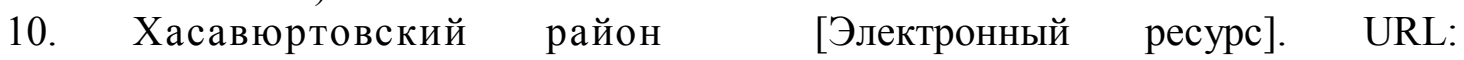
http://www.odnoselchane.ru (дата обращения 01.06.2013 г.). 